\section{Regional Analysis of Production Practices and Technology Use in the U.S. Nursery Industry}

\author{
Alan W. Hodges ${ }^{1,5}$ \\ Department of Food \& Resource Economics, University of Florida, 1115 \\ McCarty Hall, P.O. Box 110240, IFAS, Gainesville, FL 32611
}

Charles R. Hall ${ }^{2}$

Department of Horticultural Science, Texas A\&M University, 202

Horticulture/Forest Science Building, 2133 TAMU, College Station, TX

Bridget K. Behe ${ }^{3}$

Department of Horticulture, Michigan State University, A238 Plant \& Soil

Sciences, East Lansing, MI

\section{Jennifer H. Dennis ${ }^{4}$ \\ Departments of Horticulture \& Landscape Architecture and Agricultural Economics, Purdue University, 625 Agriculture Mall Drive, West Lafayette, IN}

Additional index words. survey, regions, production

\begin{abstract}
The National Nursery Survey has been conducted four times at 5-year intervals (1988, 1993, 1998, and 2003) by a multistate research committee on economics and marketing to help fill the void of publicly available information on management characteristics of the nursery industry. For the first time in 2003, the National Nursery Survey was conducted using a standard sampling methodology with 15,588 total firms representing 44 states. The objective of this study was to provide a regional analysis of nursery production practices, because production practices and technology use may differ across regions in response to varying economic and environmental conditions. From analysis of the $\mathbf{2 4 8 5}$ returned surveys, firms in the northern and interior regions of the country with more seasonal activity made greater use of temporary labor. Containerized growing systems were the predominant system throughout the United States; however, firms in the Southeast, South Central, and Pacific coast regions used this system to a greater degree, whereas firms in other regions also commonly used bare root and balled and burlapped systems. Nurseries in the Southeast region, with a warmer climate, used Integrated Pest Management practices more prevalently. Most regions had a significant share of total production from native American plants, approaching or exceeding $20 \%$ of total sales, except the Pacific region. In some regions, forwardcontracting accounted for a significantly higher share of total sales, perhaps indicating greater aversion to market risk. The Mountain region stood out for its high level of adoption of computer technologies for production, marketing, and management. Data on water use and irrigation technology did not indicate any clear pattern with respect to regional differences in relation to water scarcity.
\end{abstract}

Received for publication 29 Apr. 2008. Accepted for publication 1 July 2008 .

The National Nursery Survey was conducted by the Green Industry Research Consortium (S-1021 Multi-state Research Committee), a group of agricultural economists and horticulturists from 24 land-grant institutions in the United States. The survey was coordinated by John Brooker (Professor Emeritus) at the University of Tennessee.

The Consortium thanks financial supporters of this study: USDA-Forest Service, National Urban and Community Forestry Advisory Committee, Horticulture Research Institute, and American Nursery and Landscape Association.

${ }^{1}$ Associate Extension Scientist.

${ }^{2}$ Professor and Ellison Endowed Chair in International Floriculture.

${ }^{3}$ Professor.

${ }^{4}$ Assistant Professor

${ }^{5}$ To whom reprint requests should be addressed; e-mail awhodges@ufl.edu
The U.S. Green industry, including nursery and greenhouse producers, landscape services firms, and wholesale and retail distributors, has grown dramatically during the past 2 decades, becoming an increasingly important sector of American agriculture. In 2002, the Green industry generated 1.96 million jobs and $\$ 147.8$ billion in output (sales), and $\$ 95.1$ billion in value-added (income) in 2004 dollars, including the multiplier effects of supply chain input purchases and employee household spending (Hall et al., 2006). In 2006, sales of U.S. nursery and greenhouse crops reached $\$ 16.9$ billion (Jerardo, 2007). Despite its growing importance, however, the production and management practices followed in this industry have not been well documented.

The National Nursery Survey was conducted four times at 5-year intervals, in 1988,
1993, 1998, and 2003, by the U.S. Department of Agriculture (USDA) multistate committee on economics and marketing of horticultural products. Mail surveys were used to collect information on selected production and marketing practices such as distribution channels, interstate and international shipments, advertising expenditures, selling methods, and other information. The goal of these surveys was to help fill the void of publicly available information on management characteristics of the nursery and greenhouse industry and to provide information useful to growers, allied industry professionals, extension personnel, and researchers. Results of the National Nursery Surveys were reported by Brooker and Turner (1990) and Brooker et al. (1995, 2000, 2005). For the first time, in 2003, the National Nursery Survey was conducted using a standard sampling methodology with a total of 44 states participating, giving unprecedented coverage for the survey.

The objective of this article is to provide a regional analysis of nursery production practices and technology uses of nursery firms. Our hypothesis was that these would differ substantially across regions of the United States in response to varying economic and environmental conditions. The specific production practices examined in this article include the types of nursery media rooting systems used (containers, balled and burlap, field grown, and so on), sources of irrigation water and application methods, adoption of integrated pest management practices, and the prevalence of native plants in nursery product portfolios. These practices were of particular interest given the recent emphasis on producing plants in an environmentally sustainable manner (Brumfield, 2000). Additionally, with water conservation and quality issues increasingly affecting the ability to produce and market nursery products, it is imperative to document the efforts made in the Green industry to improve the efficiency of water applications in the nursery and/or greenhouse (Mathers et al., 2005).

The other practices examined in this article pertain to adoption of new technologies. First, the tradeoff of automation technology with labor is measured by looking at trends in employment levels for seasonal and permanent employees. In addition, brokered and contractual sales were examined as well as the level of computerization of different managerial functions. The prevalence of industry alliances points to the increased use and sophistication of various communication technologies. Many firms also are counting on positive economies of scope in managing multiple-site production. This article helps to describe these tendencies by measuring the current and projected levels of technology adoption by nursery and greenhouse managers.

\section{Materials and Methods}

Questions on the National Nursery Survey evolved over time, reflecting changes in the industry. For example, questions about 
market channels were revised to capture sales made to mass merchandise or chain stores, home centers, multiple-location garden centers, and rewholesalers. Several new questions were added to the most recent survey to characterize water use and sources of irrigation water, sales of native plants, and use of integrated pest management (IPM) practices.

A listing of over 38,000 U.S. nursery firms in 44 states was obtained from state trade associations and phytosanitary regulatory agencies. The only states not surveyed were Alaska, Alabama, Arizona, Wisconsin, Kansas, and Maryland, which declined to participate for various reasons. Firms on the list were stratified into four size classes based on production area or inventory of plants. A sample of 15,588 firms was selected from the population to receive the survey, including $100 \%$ of the large firms (20 or more acres production area), a random selection of $60 \%$ of the medium-sized (5 to 19 acres), and small-sized ( 1 to 4 acres) firms, and $40 \%$ of firms of undetermined size (Table 1).

The focus of interest was regional differences in nursery production and technology practices. Analysis of the pooled state data were conducted for eight geographic regions: Appalachia, Great Plains, Midwest, Mountain, Northeast, Pacific, South Central, and Southeast (Fig. 1). These regions were delineated to broadly represent agroclimatic zones, subject to state boundaries, and closely correspond to the USDA "Farm Production Regions." Differences in mean values for survey results across regions were evaluated using Duncan's multiple range test with Statistica software (StatSoft, Tulsa, OK); statistically significant differences $(P<0.05)$ are indicated by different letters for nonhomogeneous regional groups.

\section{Results and Discussion}

A total of 2485 usable questionnaires were returned, representing an overall response rate of $15.9 \%$ (Table 1). The largest number of respondents were in the Northeast (557), Southeast (584), Midwest (418), Pacific (316), and Appalachian regions (302) followed by the South Central (169), Great Plains (56), and Mountain (83) regions (Table 1).

Information on annual sales for each firm was collected as an approximate value or as a range of values with a point estimate at the midpoint or average of the sales range reported (Table 2). Sales for each product type, market channel, and region were estimated from the annual sales together with the percentage share reported by each firm. Nursery sales in 2003 reported by survey respondents totaled $\$ 2.73$ billion, which represented average sales of $\$ 1.15$ million per firm. Over half $(55 \%)$ of firms had sales of less than $\$ 250,000,21 \%$ of firms had sales of $\$ 250,000$ to $\$ 999,000,18 \%$ had sales of $\$ 1$ to $\$ 9$ million, and $2.3 \%$ had sales of $\$ 10$ million or greater. Approximately $4.5 \%$ of firms did not provide sales information. Firms with at least $\$ 1$ million in sales represented $20 \%$ of

Table 1. U.S. nursery firm population, survey sample size, response rate, reported sales, and employment by state and region in 2003 .

\begin{tabular}{|c|c|c|c|c|c|c|}
\hline \multirow[b]{2}{*}{ Region/state } & \multicolumn{3}{|c|}{ Number of firms } & \multirow{2}{*}{$\begin{array}{l}\text { Response } \\
\text { rate } \\
\text { (percent) }\end{array}$} & \multirow{2}{*}{$\begin{array}{c}\text { Reported } \\
\text { sales } \\
(\$ 1000)\end{array}$} & \multirow{2}{*}{$\begin{array}{c}\text { Reported } \\
\text { employmen } \\
\text { (jobs) }\end{array}$} \\
\hline & Population & Sampled & Responded & & & \\
\hline Appalachia & 3,669 & 1,719 & 302 & 17.6 & 314,659 & 5,090 \\
\hline Kentucky & 389 & 175 & 31 & 17.7 & 20,142 & 409 \\
\hline North Carolina & 1,373 & 542 & 96 & 17.7 & 142,376 & 1,951 \\
\hline Tennessee & 1,373 & 690 & 97 & 14.1 & 72,376 & 1,264 \\
\hline Virginia & 377 & 211 & 50 & 23.7 & 64,050 & 1,128 \\
\hline West Virginia & 158 & 101 & 28 & 27.7 & 15,717 & 338 \\
\hline Great Plains & 497 & 278 & 56 & 20.1 & 21,156 & 909 \\
\hline North Dakota & 33 & 33 & 12 & 36.4 & 3,958 & 255 \\
\hline Nebraska & 362 & 145 & 25 & 17.2 & 12,723 & 328 \\
\hline South Dakota & 102 & 100 & 19 & 19.0 & 4,475 & 326 \\
\hline Midwest & 5,992 & 2,397 & 418 & 17.4 & 380,034 & 7,034 \\
\hline Iowa & 376 & 148 & 24 & 16.2 & 9,156 & 333 \\
\hline Illinois & 1,122 & 528 & 88 & 16.7 & 78,375 & 1,541 \\
\hline Indiana & 435 & 198 & 34 & 17.2 & 32,280 & 625 \\
\hline Michigan & 1,509 & 576 & 98 & 17.0 & 97,206 & 1,766 \\
\hline Minnesota & 548 & 218 & 39 & 17.9 & 33,741 & 917 \\
\hline Missouri & 576 & 143 & 14 & 9.8 & 19,870 & 99 \\
\hline Ohio & 1,427 & 586 & 121 & 20.6 & 109,406 & 1,753 \\
\hline Mountain & 868 & 528 & 83 & 15.7 & 67,863 & 1,414 \\
\hline Colorado & 201 & 99 & 17 & 17.2 & 30,001 & 426 \\
\hline Idaho & 287 & 115 & 14 & 12.2 & 5,288 & 180 \\
\hline Montana & 49 & 48 & 11 & 22.9 & 11,203 & 277 \\
\hline Nevada & 78 & 72 & 11 & 15.3 & 2,141 & 67 \\
\hline Utah & 159 & 101 & 19 & 18.8 & 18,028 & 405 \\
\hline Wyoming & 94 & 93 & 11 & 11.8 & 1,202 & 59 \\
\hline Northeast & 8,070 & 3,660 & 557 & 15.2 & 573,158 & 7,602 \\
\hline Connecticut & 278 & 108 & 23 & 21.3 & 55,028 & 557 \\
\hline Delaware & 131 & 131 & 25 & 19.1 & 3,017 & 41 \\
\hline Massachusetts & 180 & 101 & 20 & 19.8 & 47,105 & 692 \\
\hline Maine & 800 & 223 & 44 & 19.7 & 8,680 & 149 \\
\hline New Hampshire & 58 & 56 & 16 & 28.6 & 24,616 & 393 \\
\hline New Jersey & 959 & 443 & 64 & 14.4 & 113,275 & 1,106 \\
\hline New York & 2,678 & 1,339 & 177 & 13.2 & 225,331 & 2,460 \\
\hline Pennsylvania & 2,686 & 1,072 & 156 & 14.6 & 85,918 & 1,902 \\
\hline Rhode Island & 87 & 86 & 12 & 14.0 & 6,770 & 168 \\
\hline Vermont & 212 & 101 & 20 & 19.8 & 3,416 & 134 \\
\hline Pacific & 5,007 & 1,855 & 316 & 17.0 & 472,103 & 7,728 \\
\hline California & 2,504 & 1,004 & 128 & 12.7 & 201,360 & 3,212 \\
\hline Hawaii & 313 & 99 & 14 & 14.1 & 34,314 & 168 \\
\hline Oregon & 1,781 & 599 & 148 & 24.7 & 227,839 & 4,099 \\
\hline Washington & 409 & 153 & 26 & 17.0 & 8,590 & 249 \\
\hline South Central & 3,802 & 1,440 & 169 & 11.7 & 180,386 & 4,542 \\
\hline Arkansas & 121 & 121 & 28 & 23.1 & 5,708 & 212 \\
\hline Louisiana & 881 & 316 & 44 & 13.9 & 24,773 & 725 \\
\hline New Mexico & 173 & 100 & 17 & 17.0 & 12,416 & 224 \\
\hline Oklahoma & 468 & 167 & 15 & 9.0 & 49,343 & 860 \\
\hline Texas & 2,158 & 736 & 65 & 8.8 & 88,146 & 2,521 \\
\hline Southeast & 6,946 & 3,711 & 584 & 15.7 & 719,491 & 8,440 \\
\hline Florida & 4,498 & 2,854 & 474 & 16.6 & 603,828 & 7,146 \\
\hline Georgia & 1,279 & 421 & 56 & 13.3 & 55,957 & 902 \\
\hline Mississippi & 500 & 177 & 22 & 12.4 & 34,665 & 223 \\
\hline South Carolina & 669 & 259 & 32 & 12.4 & 25,041 & 169 \\
\hline All states/regions & 34,852 & 15,588 & 2,485 & 15.9 & $2,728,850$ & 42,759 \\
\hline
\end{tabular}

respondents and accounted for $88 \%$ of total sales reported. Missing data on sales were estimated for some respondents who reported employment based on average sales per employee. USDA (Jerardo, 2007) reported 2003 wholesale value of sales for 7742 nursery firms at $\$ 3.97$ billion.

Permanent and temporary employment. Survey respondents reported a total of 42,759 employees in 2003 , of which $53 \%$ were fulltime and $47 \%$ were temporary, part-time, or seasonal employees. Approximately twothirds $(66 \%)$ of respondents reported hiring temporary employees. The overall average number of employees per firm was 9.9 permanent and 8.9 temporary. Total sales per employee averaged $\$ 58,600$. Firms in the Pacific region had the highest mean permanent employment (18.7) followed by the South Central and Southeast (Table 3). Firms in the Great Plains, Midwest, Mountain, and Northeast regions had the lowest permanent employment but the highest employment of temporary, part-time, or seasonal employees, indicating a higher reliance on temporary labor in these regions with reduced business activity during cold winter periods. Over half $(57 \%)$ of firms indicated that their employment had remained the same over the past 5 years, whereas $29 \%$ reported that it had increased and $15 \%$ said it had decreased. Firms in the Mountain and Southeast 
regions had the highest percentage change in permanent employment (greater than 16\%), whereas the Great Plains had the lowest (6\%). There were no regional differences in percentage change in temporary employment.

Nursery rooting media systems. Container-grown products were the dominant root packaging category in 35 of the 44 states in the survey with an overall average of $51.8 \%$ of respondents, and there were four regions for which more than half the sales were containerized plant materials (Table 4). One would expect the share of containerized plant sales to be highest in the Southeast, South Central, and Pacific regions, which have minimal risk of freeze damage to roots, and indeed this was the case. Sales of balled and burlapped $(\mathrm{B} \& \mathrm{~B})$ plants were a distant second with an overall share of $16.3 \%$ and the greatest number being sold in the Midwest region $(33.5 \%$ of sales). Bare root sales ranged from only $5 \%$ of sales in the Northeast to nearly $15 \%$ in the South Central region. The means for the "other" category were not separated because it included the combined sales of balled and potted, processed balled, field grow-bags, in-ground containers (potin-pot), and other unspecified product forms. Pot-in-pot production systems, although becoming increasingly popular, represented less than $2 \%$ of sales in all regions, ranging from $0.4 \%$ in the Pacific to $1.8 \%$ in the Great Plains region.

Irrigation. Availability of water supplies for irrigation by nursery producers is an increasingly critical issue in many parts of the United States. A section of the survey inquired about sources of irrigation water and changes in water use over the past 5 years. The categories of sources of irrigation water were natural surface, recaptured, city, or wells. Overall, $51.6 \%$ of all respondents used irrigation water supplied by wells, although this ranged from $27 \%$ in the Appalachian region to nearly $72 \%$ in the Southeast (Table 5 ). Natural surface water was the next most important source and supplied water for $26.5 \%$ of respondents overall, but ranged from $14 \%$ in the South Central region to $45 \%$ in the Appalachian region. Recaptured water was a source for less than $5 \%$ percent of respondents, except in the Appalachian region $(8.6 \%)$. City water was most important in the Mountain, Pacific, and South Central regions with $20.8 \%, 24.3 \%$, and $29.6 \%$ of respondents using this source, respectively.

Another survey question asked whether use of irrigation water over the past 5 years (on a per-acre basis) had increased, remained the same, or decreased. If there was a change, respondents were asked to provide a percentage estimate. In general, it appeared that the majority of firms held water use on a per-acre basis constant, whereas most of the remaining share of firms increased rather than decreased water use. Nurseries in the Southeast, Mountain, and Pacific regions maintained relative constant use of water, whereas more of the Great Plains, Northeast, Midwest, Appalachian, and South Central region nurseries indicated a slight increase in the

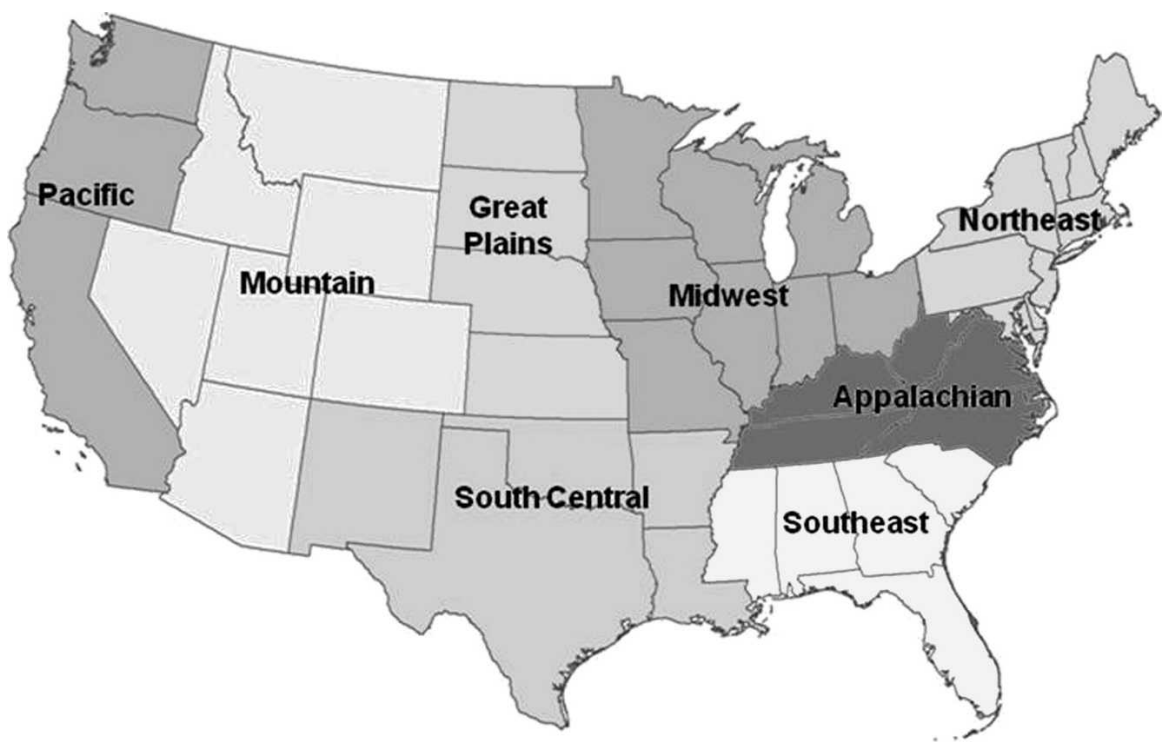

Fig. 1. U.S. regions for analysis of the nursery industry. Note: Pacific region includes Hawaii.

Table 2. Sales for 2003 reported by U.S. nursery firms responding to the National Nursery Survey.

\begin{tabular}{|c|c|c|c|c|c|}
\hline \multirow[b]{2}{*}{ Annual sales range } & \multirow{2}{*}{$\begin{array}{c}\text { Midpoint or } \\
\text { avg value }^{\mathrm{z}}(\$ 1,000)\end{array}$} & \multicolumn{2}{|c|}{ Respondents } & \multicolumn{2}{|c|}{ Total sales } \\
\hline & & Number & Percent & $\$ 1,000$ & Percent \\
\hline$<\$ 250,000$ & 40.6 & 1,367 & 55.0 & 55,314 & 2.0 \\
\hline$\$ 250,000$ to $\$ 499,999$ & 367.4 & 264 & 10.6 & 96,986 & 3.6 \\
\hline$\$ 500,000$ to $\$ 999,999$ & 703.5 & 248 & 10.0 & 174,466 & 6.4 \\
\hline$\$ 1$ to $\$ 1.99$ million $(\mathrm{Mn})$ & $1,447.7$ & 201 & 8.1 & 290,991 & 10.7 \\
\hline$\$ 2$ to $\$ 2.99 \mathrm{Mn}$ & $2,388.5$ & 99 & 4.0 & 236,459 & 8.7 \\
\hline$\$ 3$ to $\$ 3.99 \mathrm{Mn}$ & $3,440.0$ & 44 & 1.8 & 151,360 & 5.5 \\
\hline$\$ 4$ to $\$ 4.99 \mathrm{Mn}$ & $4,250.0$ & 19 & 0.8 & 80,750 & 3.0 \\
\hline$\$ 5$ to $\$ 9.99 \mathrm{Mn}$ & $7,425.0$ & 74 & 3.0 & 549,450 & 20.1 \\
\hline$\$ 10$ to $\$ 14.99 \mathrm{Mn}$ & $12,500.0$ & 24 & 1.0 & 297,000 & 10.9 \\
\hline$\$ 15$ to $\$ 19.99 \mathrm{Mn}$ & $17,500.0$ & 8 & 0.3 & 140,000 & 5.1 \\
\hline$\geq \$ 20 \mathrm{Mn}$ & $20,000.0$ & 26 & 1.0 & 656,075 & 24.0 \\
\hline Not available & NA & 111 & 4.5 & NA & NA \\
\hline Total/all & & 2485 & 100 & $2,728,850$ & 100 \\
\hline
\end{tabular}

${ }^{\mathrm{z}}$ Average value for firms reporting actual sales.

$\mathrm{NA}=$ not applicable.

Table 3. Mean and percent change in number of permanent and temporary nursery employees in nurseries surveyed in eight U.S. regions in $2003^{z}$.

\begin{tabular}{lcccc}
\hline Region & $\begin{array}{c}\text { Permanent } \\
\text { employees } \\
(\text { mean })\end{array}$ & $\begin{array}{c}\text { Temporary } \\
\text { employees } \\
(\text { mean })\end{array}$ & $\begin{array}{c}\text { Permanent } \\
\text { employees } \\
\text { changed (percent) }\end{array}$ & $\begin{array}{c}\text { Temporary } \\
\text { employees } \\
\text { changed (percent) }\end{array}$ \\
\hline Appalachia & $9.6 \mathrm{bc}$ & $8.0 \mathrm{ab}$ & $14.4 \mathrm{ab}$ & $17.5 \mathrm{a}$ \\
Great Plains & $4.9 \mathrm{c}$ & $13.6 \mathrm{a}$ & $6.3 \mathrm{~b}$ & $15.1 \mathrm{a}$ \\
Midwest & $6.2 \mathrm{c}$ & $13.2 \mathrm{a}$ & $8.6 \mathrm{ab}$ & $12.9 \mathrm{a}$ \\
Mountain & $7.5 \mathrm{c}$ & $14.3 \mathrm{a}$ & $16.2 \mathrm{a}$ & $13.1 \mathrm{a}$ \\
Northeast & $6.8 \mathrm{c}$ & $9.3 \mathrm{ab}$ & $12.8 \mathrm{ab}$ & $12.2 \mathrm{a}$ \\
Pacific & $18.7 \mathrm{a}$ & $11.2 \mathrm{a}$ & $12.5 \mathrm{ab}$ & $12.7 \mathrm{a}$ \\
South Central & $17.3 \mathrm{ab}$ & $12.6 \mathrm{a}$ & $16.5 \mathrm{a}$ & $10.7 \mathrm{a}$ \\
Southeast & $11.6 \mathrm{abc}$ & $4.5 \mathrm{~b}$ & 1.5 & 12.2 \\
\hline All regions & 9.9 & 8.9 & $\mathrm{ab}$ & \\
\hline
\end{tabular}

${ }^{2}$ Table entries followed by different letters indicate statistically different values $(P<0.05$ level).

Table 4. Rooting media systems used in by surveyed nurseries in eight U.S. regions in $2003^{z}$.

\begin{tabular}{|c|c|c|c|c|}
\hline \multirow[b]{2}{*}{ Region } & Container & Bare root & Balled and burlapped & $\overline{\text { Other media }}$ \\
\hline & \multicolumn{4}{|c|}{ 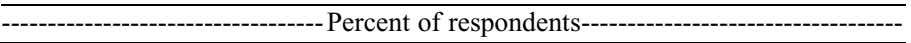 } \\
\hline Appalachia & $40.5 \mathrm{c}$ & $10.6 \mathrm{abc}$ & $28.5 \mathrm{~cd}$ & 16.2 \\
\hline Great Plains & $30.5 \mathrm{~b}$ & $7.9 \mathrm{ab}$ & $23.3 \mathrm{bc}$ & 38.3 \\
\hline Midwest & $30.0 \mathrm{~b}$ & $9.0 \mathrm{abc}$ & $33.5 \mathrm{~d}$ & 24.6 \\
\hline Mountain & $54.5 \mathrm{ad}$ & $7.6 \mathrm{ab}$ & $23.8 \mathrm{bc}$ & 11.8 \\
\hline Northeast & $49.3 \mathrm{~cd}$ & $5.3 \mathrm{a}$ & $20.1 \mathrm{~b}$ & 22.5 \\
\hline Pacific & $60.8 \mathrm{a}$ & $12.6 \mathrm{bc}$ & $6.5 \mathrm{a}$ & 15.3 \\
\hline Southeast & $72.7 \mathrm{e}$ & $6.6 \mathrm{ab}$ & $10.5 \mathrm{a}$ & 14.2 \\
\hline South Central & $60.7 \mathrm{a}$ & $14.5 \mathrm{c}$ & $6.5 \mathrm{a}$ & 8.4 \\
\hline All regions & 51.8 & 8.4 & 18.6 & 18.0 \\
\hline
\end{tabular}

zTable entries followed by different letters indicate statistically different values $(P<0.05)$. Note that percentages may not sum to $100 \%$ within each region as a result of independent values reported. 
Table 5. Water sources used for irrigation by surveyed nurseries in eight U.S. regions in $2003^{z}$.

\begin{tabular}{|c|c|c|c|c|}
\hline \multirow[b]{2}{*}{ Region } & Wells & Natural surface & Recaptured & City (municipal) \\
\hline & \multicolumn{4}{|c|}{ 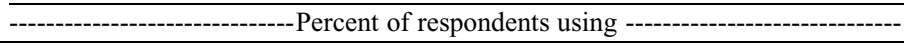 } \\
\hline Appalachia & $27.2 \mathrm{c}$ & $45.1 \mathrm{c}$ & $8.6 \mathrm{~b}$ & $15.4 \mathrm{c}$ \\
\hline Great Plains & $62.2 \mathrm{~b}$ & $18.6 \mathrm{ab}$ & $2.5 \mathrm{a}$ & $12.5 \mathrm{ab}$ \\
\hline Midwest & $44.8 \mathrm{a}$ & $39.8 \mathrm{c}$ & $3.5 \mathrm{a}$ & $6.3 \mathrm{a}$ \\
\hline Mountain & $51.9 \mathrm{a}$ & $22.9 \mathrm{ab}$ & $4.4 \mathrm{a}$ & $20.8 \mathrm{c}$ \\
\hline Northeast & $49.6 \mathrm{a}$ & $27.8 \mathrm{~b}$ & $3.5 \mathrm{a}$ & $14.6 \mathrm{bc}$ \\
\hline Pacific & $49.9 \mathrm{a}$ & $19.9 \mathrm{ab}$ & $3.8 \mathrm{a}$ & $24.3 \mathrm{c}$ \\
\hline Southeast & $71.6 \mathrm{~b}$ & $16.1 \mathrm{a}$ & $3.7 \mathrm{a}$ & $6.6 \mathrm{a}$ \\
\hline South Central & $49.8 \mathrm{a}$ & $13.5 \mathrm{a}$ & $4.7 \mathrm{a}$ & $29.6 \mathrm{c}$ \\
\hline All regions & 51.1 & 26.5 & 4.3 & 14.3 \\
\hline
\end{tabular}

${ }^{2}$ Table entries followed by different letters indicate statistically different values $(P<0.05)$. Note that percentages may not sum to $100 \%$ within each region as a result of independent values reported.

Table 6. Irrigation methods used by surveyed nurseries in eight U.S. regions in $2003^{z}$.

\begin{tabular}{|c|c|c|c|c|}
\hline \multirow[b]{2}{*}{ Region } & Overhead irrigation & Drip irrigation & Subirrigation & Other methods \\
\hline & \multicolumn{4}{|c|}{ 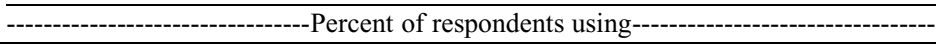 } \\
\hline Appalachia & $64.4 \mathrm{a}$ & $38.0 \mathrm{a}$ & $1.6 \mathrm{a}$ & $8.0 \mathrm{c}$ \\
\hline Great Plains & $41.7 \mathrm{~b}$ & $37.5 \mathrm{a}$ & $10.4 \mathrm{c}$ & $20.8 \mathrm{~b}$ \\
\hline Midwest & $55.4 \mathrm{a}$ & $33.5 \mathrm{a}$ & $3.1 \mathrm{ab}$ & $13.5 \mathrm{abc}$ \\
\hline Mountain & 65.9 a & $46.6 \mathrm{ab}$ & $22.7 \mathrm{~d}$ & $13.6 \mathrm{abc}$ \\
\hline Northeast & $58.5 \mathrm{a}$ & $39.1 \mathrm{a}$ & $5.2 \mathrm{abc}$ & $14.4 \mathrm{abc}$ \\
\hline Pacific & $63.8 \mathrm{a}$ & $44.7 \mathrm{ab}$ & $6.4 \mathrm{abc}$ & $18.7 \mathrm{ab}$ \\
\hline Southeast & $77.6 \mathrm{c}$ & $52.4 \mathrm{~b}$ & $4.6 \mathrm{abc}$ & $10.1 \mathrm{ac}$ \\
\hline South Central & $61.6 \mathrm{a}$ & $39.1 \mathrm{a}$ & $7.5 \mathrm{bc}$ & $18.8 \mathrm{ab}$ \\
\hline All regions & 62.7 & 40.6 & 5.3 & 13.4 \\
\hline
\end{tabular}

${ }^{2}$ Table entries followed by different letters indicate statistically different values $(P<0.05)$. Note that percentages may not sum to $100 \%$ within each region as a result of independent values reported.

Table 7. Native plant sales as a percentage of total sales by surveyed nurseries in eight U.S. regions in $2003^{z}$.

\begin{tabular}{lc}
\hline Region & Percent of sales \\
\hline Appalachia & $27.1 \mathrm{a}$ \\
Great Plains & $25.9 \mathrm{a}$ \\
Midwest & $23.2 \mathrm{a}$ \\
Mountain & $23.9 \mathrm{a}$ \\
Northeast & $19.7 \mathrm{ab}$ \\
Pacific & $13.2 \mathrm{~b}$ \\
South Central & $23.9 \mathrm{a}$ \\
Southeast & $22.5 \mathrm{a}$ \\
\hline All regions & 21.9 \\
\hline
\end{tabular}

${ }^{\mathrm{z}}$ Table entries followed by different letters indicate statistically different values $(P<0.05)$ amount of water used on a per-acre basis. The change in irrigation water used ranged from a $6.9 \%$ increase in the Mountain region to a $12.1 \%, 12.8 \%$, and $15.5 \%$ increase in the Appalachian, Northeast, and South Central regions, respectively.

Overhead irrigation systems were used by the majority of nursery firms responding, ranging from $42 \%$ usage in the Great Plains to $78 \%$ in the Southeast (Table 6). Other major irrigation systems used included drip irrigation, particularly in the Pacific (44.7\%), Mountain (46.6\%), and Southeast (52.4\%) regions. Subirrigation methods were seldom used except in the Great Plains (10.4\%) and
Mountain (22.7\%) regions. Almost 21\% of the Great Plains nurseries used irrigation systems other than those specified. Note that respondents were allowed to choose more than one type of water source or irrigation system, so percentages may not sum to $100 \%$.

Native plants. Native plants have become increasingly important in the U.S. nursery industry as a result of growing consumer awareness about invasive exotics and mandates by local governments that specify a minimum percentage of natives in new landscapes (Zimmerman and Ankersen, 2005). Native plants were defined in the survey questionnaire as those present in a state before European settlement. This question simply asked for the percent of total sales of native plants. Annual sales values provided by the respondents were used to weight the sales percentages reported for this question. For the total sample, $21.9 \%$ of total sales were accounted for by native plants in 2003 . Table 7 presents the breakdown of sales of native plants by region.

Integrated pest management. Integrated pest management has become an established approach to pest management in the nursery and greenhouse industry in the face of increased chemical and application costs, chemical resistance of pests, and worker safety and environmental issues. Use of IPM practices was assessed for the first time in the most recent National Nursery Survey. The most commonly used practices (Table 8), reported by at least half of respondents, were removing infested plants or plant parts $(88 \%)$, cultivation and hand weeding $(77 \%)$, spot treatment with pesticides instead of broadcast spraying (73\%), inspecting incoming stock for insects/diseases $(72 \%)$, alternating pesticides to avoid pesticide resistance $(63 \%)$, and elevating plants for air circulation $(60 \%)$. Other common practices used by onethird to one-half of respondents were ventilating greenhouses $(45 \%)$, adjusting fertilization

Table 8. Integrated pest management (IPM) practices used by surveyed nurseries in eight U.S. regions in $2003^{z}$.

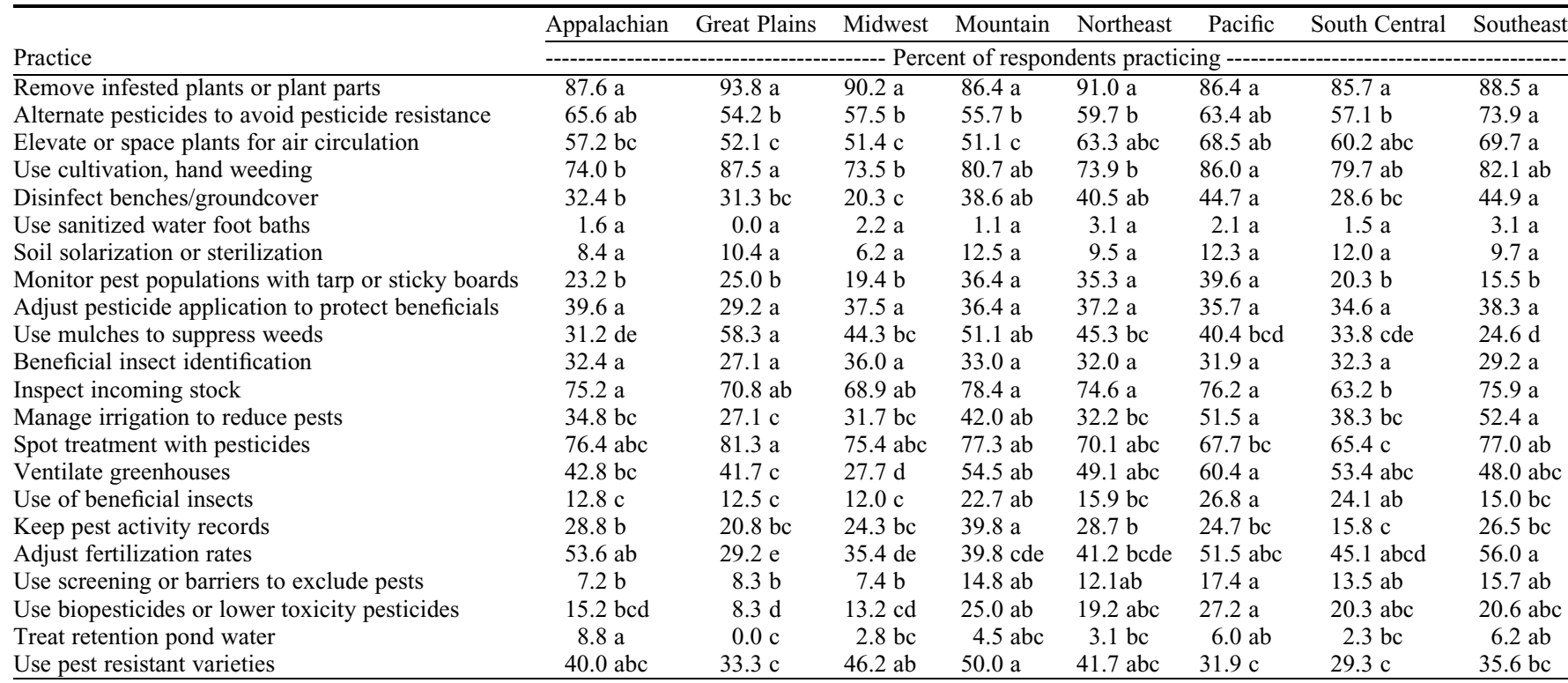

${ }^{\mathrm{z}}$ Table entries followed by different letters indicate statistically different values $(P<0.05)$. 
rates to control weed/pest growth (45\%), managing irrigation to reduce pests $(39 \%)$, using pest-resistant varieties $(38 \%)$, using mulches to suppress weeds (37\%), adjusting pesticide application to protect beneficials (37\%), and disinfecting benches or groundcovers $(36 \%)$.

Significant regional differences were seen in many of the IPM practices. In the Southeast region, where pest pressures are generally very high, there were high rates of practices to alternate pesticides to avoid

Table 9. Brokerage practices by surveyed nurseries in eight U.S. regions in $2003^{z}$.

\begin{tabular}{lcc}
\hline Region & $\begin{array}{c}\text { Firms brokering } \\
\text { plants (percent) }\end{array}$ & $\begin{array}{c}\text { Sales brokered } \\
\text { (percent) }\end{array}$ \\
\hline Appalachia & $44.8 \mathrm{~b}$ & $11.2 \mathrm{~b}$ \\
Great Plains & $52.1 \mathrm{ab}$ & $18.9 \mathrm{a}$ \\
Midwest & $55.4 \mathrm{ab}$ & $15.6 \mathrm{ab}$ \\
Mountain & $60.2 \mathrm{a}$ & $17.9 \mathrm{ab}$ \\
Northeast & $51.9 \mathrm{ab}$ & $15.1 \mathrm{ab}$ \\
Pacific & $44.6 \mathrm{~b}$ & $13.0 \mathrm{ab}$ \\
South Central & $50.4 \mathrm{ab}$ & $17.3 \mathrm{ab}$ \\
Southeast & $50.6 \mathrm{ab}$ & $15.3 \mathrm{ab}$ \\
\hline All regions & 49.4 & 15.0 \\
\hline
\end{tabular}

${ }^{\mathrm{z}}$ Table entries followed by different letters indicate statistically different values $(P<0.05)$.

Table 10. Product contracting by surveyed nurseries in eight U.S. regions in $2003^{z}$.

\begin{tabular}{lcccccc}
\hline & $\begin{array}{c}\text { Share of } \\
\text { production } \\
\text { contracted } \\
\text { (Percent) }\end{array}$ & $\begin{array}{c}\text { Other } \\
\text { producers }\end{array}$ & $\begin{array}{c}\text { Retail garden } \\
\text { centers }\end{array}$ & $\begin{array}{c}\text { Mass } \\
\text { merchandisers }\end{array}$ & Cooperatives & $\begin{array}{c}\text { Other } \\
\text { buyers }\end{array}$ \\
Region & $12.2 \mathrm{ab}$ & $17.2 \mathrm{a}$ & $13.6 \mathrm{a}$ & $8.4 \mathrm{ab}$ & $3.2 \mathrm{a}$ & $11.6 \mathrm{bc}$ \\
\hline Appalachia & $8.7 \mathrm{~b}$ & $14.6 \mathrm{a}$ & $18.8 \mathrm{a}$ & $0.0 \mathrm{c}$ & $2.0 \mathrm{a}$ & $10.4 \mathrm{c}$ \\
Great Plains & $11.5 \mathrm{ab}$ & $12.6 \mathrm{a}$ & $12.9 \mathrm{a}$ & $2.5 \mathrm{bc}$ & $1.5 \mathrm{a}$ & $12.0 \mathrm{bc}$ \\
Midwest & $12.1 \mathrm{ab}$ & $13.6 \mathrm{a}$ & $14.8 \mathrm{a}$ & $7.9 \mathrm{ab}$ & $1.1 \mathrm{a}$ & $23.9 \mathrm{a}$ \\
Mountain & $6.7 \mathrm{~b}$ & $11.4 \mathrm{a}$ & $16.8 \mathrm{a}$ & $4.0 \mathrm{bc}$ & $1.7 \mathrm{a}$ & $12.6 \mathrm{bc}$ \\
Northeast & $16.0 \mathrm{a}$ & $20.4 \mathrm{a}$ & $14.5 \mathrm{a}$ & $5.5 \mathrm{abc}$ & $1.3 \mathrm{a}$ & $20.4 \mathrm{ab}$ \\
Pacific & $10.5 \mathrm{ab}$ & $15.0 \mathrm{a}$ & $12.0 \mathrm{a}$ & $11.3 \mathrm{a}$ & $0.0 \mathrm{a}$ & $23.3 \mathrm{a}$ \\
South Central & $11.9 \mathrm{ab}$ & $18.8 \mathrm{a}$ & $12.4 \mathrm{a}$ & $6.4 \mathrm{ab}$ & $1.3 \mathrm{a}$ & $18.1 \mathrm{abc}$ \\
Southeast & 10.9 & 15.4 & 13.8 & 5.2 & 1.6 & 15.8 \\
\hline All regions & 10.9 & &
\end{tabular}

${ }^{\mathrm{z}}$ Table entries followed by different letters indicate statistically different values $(P<0.05)$.

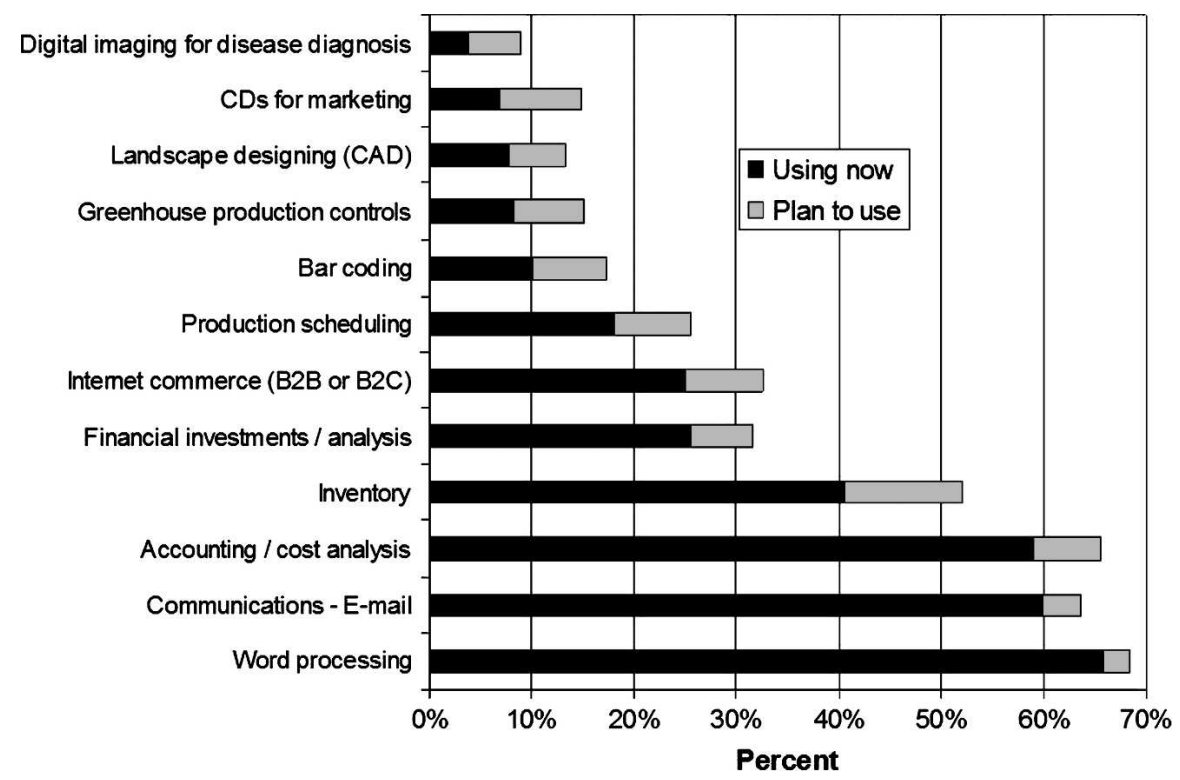

Fig. 2. Percent of surveyed U.S. nursery firms currently using (in 2003) or planning to use computers in the next 5 years by function.

chemical resistance $(74 \%)$, elevate or space plants for air circulation (70\%), adjust fertilization rates $(56 \%)$, manage irrigation to reduce pests $(52 \%)$, and disinfest benches or groundcover $(45 \%)$. The Pacific region had similarly high levels of some of these practices and, in addition, cultivation hand weeding $(86 \%)$, ventilate greenhouses $(60 \%)$, use of biopesticides or reduced toxicity pesticides $(27 \%)$, and use of beneficial insects $(27 \%)$. The Great Plains and Mounain regions had high use of mulches to suppress weeds, cultivation/hand weeding, and spot treatment with pesticides. The use of beneficial insects was also high in the Mountain (23\%) and South Central (24\%) regions. Practices that did not significantly vary regionally included removing infested plants or plant parts, using sanitized water foot baths, soil solarization, beneficial insect identification, adjusting pesticide application to protect beneficials, and inspecting incoming stock.

Brokerage. The U.S. nursery industry has a high level of trade among producing firms with sales to other growers now accounting for the largest share of sales to any single market channel. Historically, 
Table 11. Rank order of computerization for selected business functions in U.S. nurseries surveyed in eight regions in 2003.

\begin{tabular}{|c|c|c|c|c|c|c|c|c|}
\hline \multirow[b]{2}{*}{ Business function } & Appalachian & Great Plains & Midwest & Mountain & Northeast & Pacific & South Central & Southeast \\
\hline & \multicolumn{8}{|c|}{ - } \\
\hline Word processing & 4 & 7 & 5 & 1 & 8 & 3 & 2 & 6 \\
\hline Communications, e-mail & 4 & 5 & 7 & 1 & 8 & 2 & 3 & 6 \\
\hline Accounting, cost analysis & 4 & 8 & 6 & 1 & 7 & 2 & 3 & 5 \\
\hline Inventory & 4 & 8 & 3 & 1 & 7 & 2 & 5 & 6 \\
\hline Financial analysis, investments & 4 & 8 & 2 & 1 & 7 & 3 & 5 & 6 \\
\hline Internet commerce & 7 & 8 & 5 & 1 & 6 & 2 & 3 & 4 \\
\hline Production scheduling & 3 & 8 & 4 & 1 & 6 & 2 & 7 & 5 \\
\hline Bar coding & 3 & 8 & 7 & 1 & 6 & 2 & 4 & 5 \\
\hline Greenhouse control & 4 & 8 & 6 & 2 & 5 & 1 & 7 & 3 \\
\hline Landscape design (CAD) & 6 & 1 & 2 & 3 & 4 & 8 & 5 & 7 \\
\hline CDs for marketing & 6 & 8 & 5 & 1 & 7 & 4 & 3 & 2 \\
\hline Digital imaging for disease diagnosis & 4 & 8 & 6 & 7 & 3 & 5 & 1 & 2 \\
\hline Mean ranking & 4.4 & 7.1 & 4.8 & 1.8 & 6.2 & 3.0 & 4.0 & 4.8 \\
\hline
\end{tabular}

${ }^{2}$ Ranking score of $1=$ highest, $8=$ lowest.

with the exception of digital imaging for disease diagnosis (where the region ranked seventh). In fact, the Mountain region was first in nine of 12 categories. The Pacific and South Central regions also were heavily computerized, closely followed by the Appalachian, Midwest, and Southeast regions. The Northeast and Great Plains regions were well below their regional counterparts with respect to their computer use with the exception of landscape design functions in the Great Plains and digital imaging functions in the Northeast where they ranked first and third, respectively.

\section{Conclusions}

This analysis of national survey data for the nursery and greenhouse industry in the United States showed that there are distinct regional differences in production practices and technology use. In general, firms in the northern and interior regions of the country with more seasonal activity made greater use of temporary labor. Containerized growing systems are the predominant system throughout the United States; however, firms in the Southeast, South Central, and Pacific coast regions, which experience warmer winter weather and lower risk of freeze damage, use this system to a greater degree, whereas firms in other regions also commonly used bare root and B\&B systems. Regions with higher overall pest pressures as a result of warm and humid conditions, particularly the southeast United States, were found to practice IPM more prevalently. Most regions had a significant share of total production from native American plants, approaching or exceeding $20 \%$ of total sales, except in the Pacific region $(13 \%)$. In some regions, forward-contracting accounted for a significantly higher share of total sales, perhaps indicating greater aversion to market risk. The Mountain region stands out for its high level of adoption of computer technologies for production, marketing, and management. Data on water use and irrigation technology did not indicate any clear pattern with respect to regional differences in relation to water scarcity.

Given the reduction over time in the number of states included in USDA nursery reports, this study provides useful insight into a broader perspective of the nursery industry with regional comparisons. The next National Nursery Survey will be conducted in Jan. 2009.

\section{Literature Cited}

Brooker, J.R., D. Eastwood, C. Hall, K. Morris, A. Hodges, and J. Haydu. 2005. Trade flows and marketing practices within the U.S. nursery industry: 2003. Southern Coop. Series Bull. 404, Univ. of Tenn. Ag. Exp. Sta.

Brooker, J.R., R.A. Hinson, and S.C. Turner. 2000 Trade flows and marketing practices within the U.S. nursery industry: 1998. Southern Coop. Series Bull. 397, Univ. of Tenn. Agr. Exp. Sta.

Brooker, J.R. and S.C. Turner. 1990. Trade flows and marketing practices within the U.S. nursery industry. Southern Coop. Series Bulletin 358, Univ. of Tenn. Agr. Exp. Sta., Oct.

Brooker, J.R., S.C. Turner, and R.A. Hinson. 1995. Trade flows and marketing practices within the U.S. nursery industry: 1993. Southern Coop. Series Bull. 384, Univ. of Tenn. Agr. Exp. Sta.

Brumfield, R.G. 2000. An examination of the economics of sustainable and conventional horticulture. HortTechnology 10:687-691.

Hall, C.R., A.W. Hodges, and J.J. Haydu. 2006. The economic impacts of the green industry in the U.S. HortTechnology 16:345353.

Jerardo, A. 2007. Floriculture and nursery crops yearbook. USDA-Economic Research Service, FLO-2007.

Mathers, H.M., T. Yaeger, and L.T. Case. 2005. Improving irrigation water use in container nurseries. HortTechnology 15:8-12.

Zimmerman, E. and T.T. Ankersen. 2005. Model native plant landscape ordinance handbook. Prepared for Florida Native Plant Society. University of Florida, Levin College of Law, Gainesville, FL. 10 June 2008. <http://www. law.ufl.edu/conservation/pdf/MLOFinal2-62-05.pdf $>$. 